\title{
Increased seroprevalence of lgG-class antibodies against cytomegalovirus, parvovirus B19, and varicella-zoster virus in women working in child day care
}

\author{
Gini G C van Rijckevorsel ${ }^{1,5^{*}}$, Lian P M J Bovée ${ }^{1}$, Marjolein Damen², Gerard J B Sonder ${ }^{1,3}$,
}

Maarten F Schim van der Loeff ${ }^{3,4}$ and Anneke van den Hoek H,3 $^{1,3}$

\begin{abstract}
Background: Primary maternal infection with cytomegalovirus (CMV), parvovirus B19 (B19V), and varicella-zoster virus (VZV) may result in adverse pregnancy outcomes like congenital infection or foetal loss. Women working in child day care have an increased exposure to CMV, B19V, and VZV. By comparing the seroprevalence of IgG-class antibodies against CMV, VZV and B19V in female day care workers (DCW) with the seroprevalence in women not working in day care this study aimed to assess the association between occupation and infection.

Methods: A cross-sectional design was used. Out of a random sample of 266 day care centres, demographic data, data on work history, and blood samples were collected from 285 women from 38 centres. In addition, blood samples and basic demographics from women who participated in a cross-sectional survey of the Amsterdam population (2004) were used. All blood samples were tested for lgG-class antibodies against CMV, B19V, and VZV.

Results: Twenty-seven percent of the DCW were still susceptible to B19V or CMV. Working in day care was independently associated with B19V infection in all DCW (prevalence ratio [PR] 1.2; $95 \%$ Cl 1.1-1.3), and with CMV infection in DCW of European origin only (PR 1.7; $95 \% \mathrm{Cl} 1.3-2.3$ ). Almost all women born outside Europe tested seropositive for CMV (96\%). All DCW tested seropositive for VZV, compared to only $94 \%$ of the women not working in day care.
\end{abstract}

Conclusion: This study confirms the clear association between employment in child day care centres and infection with CMV and B19V. Intervention policies, like screening of new employees and awareness campaigns emphasizing hygienic measures among DCW, should be implemented urgently to improve the maternal health of these women and the health of their offspring.

Keywords: Cytomegalovirus, Parvovirus B19, Varicella-zoster virus, Seroprevalence, Child day care, Occupational risk

\section{Background}

Primary maternal infection with cytomegalovirus (CMV), parvovirus B19 (B19V), and varicella-zoster virus (VZV) may result in adverse pregnancy outcomes like congenital infection or foetal loss [1-4]. CMV is the most common congenital infection, occurring in $0.3 \%$

\footnotetext{
* Correspondence: gvrijckevorsel@ggd.amsterdam.nl

${ }^{1}$ Public Health Service Amsterdam, Department of Infectious Diseases,

Nieuwe Achtergracht 100, Amsterdam, WT 1018, The Netherlands

${ }^{5}$ Public Health Service Amsterdam, Nieuwe Achtergracht 100, Amsterdam,

WT 1018, the Netherlands

Full list of author information is available at the end of the article
}

to $1.0 \%$ of all live births worldwide. It may lead to permanent disabilities in the unborn child, such as deafness, blindness and mental impairments [5]. Primary CMV infection results in life-long latent infection, and although congenital infection after reactivation and re-infection with a different CMV strain may occur, the risk of congenital infection is highest for seronegative women [6,7]. It is difficult to identify an acute CMV infection because the disease is asymptomatic in $90 \%$ of individuals and the clinical signs, if present, are non-specific. In contrast, primary VZV infection almost always causes signs of

\section{Biomed Central}


disease, specifically, a generalized pruritic vesicular rash called chickenpox [3]. Primary maternal infection with VZV during the first 20 weeks of pregnancy only, can lead to foetal varicella syndrome in $1 \%$ to $2 \%$ of the patients, but perinatal infection can also be harmful to the newborn $[3,4,8]$. Like VZV, the risk of congenital B19V infection depends on the gestational age, with the greatest risk following maternal infection in the first 20 weeks. In about 5-10\% of pregnant women with primary $\mathrm{B} 19 \mathrm{~V}$ infection, transplacental transmission may lead to adverse pregnancy outcome like hydrops foetalis or foetal death [3,9]. After primary VZV or B19V infection, immunity is regarded as life-long $[3,9]$.

In the Netherlands, most people experience primary CMV, B19V, and VZV infection during their childhood. Vaccination against VZV is not part of the national childhood vaccination program. The identification of risk groups susceptible to these infections is important to assess the risk of infection in pregnant women. The risk of exposure is generally present as CMV, B19V, and VZV circulate widely in the population, but is particularly high in child day care centres and schools. Children attending day care have significantly higher rates of CMV excretion in their saliva and urine, compared to children not attending day care $[10,11]$. Outbreaks of VZV and B19V occur regularly in day care centres and schools. Employees of day care centres, most of whom are women of childbearing age, are repeatedly exposed to CMV, B19V, and VZV and, therefore, are considered at risk $[10,12-14]$. The purpose of this study was to provide current estimates of the seroprevalence of IgG-class antibodies against CMV, VZV, and B19V in women of childbearing age working in child day care centres in Amsterdam (DCW). By comparing these seroprevalence rates with data from Amsterdam women not working in day care, we aimed to assess the association between occupation and infection in DCW. Additionally, other likely determinants of seropositivity for CMV, B19V, and VZV, such as age and ethnic origin, were investigated.

\section{Methods}

\section{Study population and sampling procedure}

\section{Child day care workers}

Data on child day care personnel were obtained through a cross-sectional survey carried out in 2007 by the Public Health Service of Amsterdam (GGD Amsterdam). Out of 266 day care centres on the Amsterdam municipal register, a random sample of 63 was drawn. All 63 centres were invited to participate, with a response rate of $60 \%$. Thirty-eight centres were then visited; all female employees present were invited to participate, and nearly all agreed, yielding a total of 285 participants. After giving informed consent, the participants were questioned via a standardized face-to-face interview concerning socio-demographics, family size, work history, and a blood sample was collected. The samples were centrifuged and frozen at $-80{ }^{\circ} \mathrm{C}$ within $48 \mathrm{~h}$. The following variables were considered pertinent to the study: sex, age, country of birth of the participant and her parents, when applicable the age at the time of immigration, the number and age of children living with the participant currently and/or in the past, and the number of years working as a child care worker. In the analysis only women of childbearing age (16 to 44 years) were included $(n=242)$.

\section{Women not working in child day care}

Data on women not working in day care came from a cross-sectional survey of the adult Amsterdam general population, the Amsterdam Health Monitor (AHM), carried out by the Public Health Service of Amsterdam in 2004 from which a serum repository was established. AHM data was collected using frequency stratification by ethnic group, and women of Turkish and Moroccan origin were oversampled. Seroprevalence reported for this group in our study did not account for the sampling method of the AHM and basic demographic data and blood samples from all female participants in that survey aged 18 to 44 years $(n=298)$ were included. It should not be considered as representative of women in the Amsterdam general population, but rather as representative of women not working in child day care. More information on the AHM and its serum repository is described elsewhere [15-17]. Approval for both studies was obtained from the Medical Ethics Committee of the Academic Medical Centre.

\section{Serological assays}

All serum samples were tested for IgG-class antibodies against B19V by means of quantitative enzyme immunoassays (NovaLisa ${ }^{\text {тм }}$ Parvovirus B19 recombinant IgGELISA; Novatec Immundiagnostica Gmbh.; Dietzenbach, Germany). In calculating seroprevalence, samples with a positive result (cut-off $\geq 9$ NovaTec Units) were considered immune.

IgG-class antibodies against CMV were determined by a quantitative enzyme immunoassay (SERION ELISA classic Cytomegalovirus IgG/IgM; Institut Virion/Serion, Würzburg, Germany). Equivocal test results were considered seropositive.

Serum samples obtained from DCW were tested for IgG-class antibodies against VZV with quantitative enzyme immunoassays (SERION ELISA classic VaricellaZoster-Virus IgG/IgM/IgA; Institut Virion/Serion, Würzburg, Germany). To estimate VZV seropositivity in women in the Amsterdam repository, plasma samples were used and tested for IgG-class antibodies against VZV with a microplate enzyme-linked immunosorbent 
assay system (EUROIMMUN Anti-Varicella-Zoster -Virus IgG-ELISA; Medizinische Labordiagnostika AG, Lübeck, Germany). Only women whose samples had a positive result (cut-off $\geq 110 \mathrm{mIU} / \mathrm{ml}$ ) were considered immune. All assays were performed in the Public Health Laboratory in Amsterdam according to the instructions of the manufacturer.

\section{Statistical analysis}

Prevalences $(\mathrm{P})$ were compared using the chi-square test; values of $\mathrm{p}<0.05$ were considered significant. Univariable and multivariable binominal regression analysis, adjusted for day-care centre clustering, was used to estimate prevalence ratios (PR) with $95 \%$ confidence intervals (CI) based on robust standard errors. If significant at univariable level $(\mathrm{p}<0.1)$, covariates were included in a multivariable model. In the analysis the AHM data were not corrected for the sampling method. All analyses were performed in Intercooled Stata 11.1 for Windows (Stata Corp., College Station, Texas, USA).

\section{Results}

\section{Characteristics of the study sample}

Table 1 shows the characteristics of the total of 540 women aged 16 to 44 years included in the analyses; $55 \%$ (298) were women from the AHM, and $45 \%$ (242) were DCW. The median age was 32 years (interquartile range [IQR] 25-39 years). The DCW were younger than the women from the AHM (median age 29 years; IQR 24-35 years versus 35 years; IQR 28-40 years; rank sum test, $\mathrm{p}<0.001)$. Most women $(294 ; 54 \%)$ were born in the Netherlands. Of the women born elsewhere, $37 \%$ originated from Turkey, 27 \% from Morocco, $15 \%$ from Suriname or the Dutch Antilles, 10 \% from within Europe and $11 \%$ from other countries (Africa, Asia, Central and South America). Most DCW were born in Europe (77 \%), whereas women from the Amsterdam Health Monitoring Survey were more often born outside Europe (46\%). Most immigrants (59\%) arrived in the Netherlands when they were adults; the median age at migration was 20 years (range 1-42 years). Sixty-two per cent of the women were mothers, $19 \%$ had 1 child, $21 \%$ had 2 children, and $14 \%$ had 3 or more. The two groups differed in that $84 \%$ of the women of the AHM had children compared to only $42 \%$ of the DCW. Also, $84 \%$ of all women born outside Europe had one or more children compared to only $47 \%$ of all women born in the Netherlands or Europe $(\mathrm{p}<0.001)$.

\section{Seroprevalence of CMV IgG}

No valid test results for CMV were available for 11 women (1 DCW and 10 from the general Amsterdam population survey). The seroprevalence of CMV IgG antibodies among the 529 women with valid test results was $73.0 \%$ (95 \% CI 69.0-76.7\%), and was similar among DCW and among the women not working in day care. Table 2 shows the seroprevalence by demographic characteristics and the PR from univariable analysis. Seroprevalence was significantly higher among immigrants born outside Europe (96 \%) compared to women born in European countries, including the Netherlands (57\%). Nearly all of the women born in Turkey (99\%), in Morocco (98\%), or in Suriname or the Dutch Antilles (97 \%) tested IgG-seropositive for CMV. Because the seroprevalence of CMV in immigrants born outside Europe approached $100 \%$, a subgroup analysis limited to the strata of women born in Europe was performed in a separate multivariable binominal regression model. In this model, after adjusting for working in child care, for age (in categories), and for having children, CMV seroprevalence in DCW was significantly higher than among women not working in day care centres (PR 1.7; 95 \% CI 1.3-2.3; $\mathrm{p}<0.001)$, and also among those having one or more children of their own (PR 1.2; 95 \% CI 1.1-1.4; $\mathrm{p}=0.03$ ). (Data not shown).

\section{Seroprevalence of B19V lgG}

The seroprevalence of B19V IgG antibodies among all 540 women was $65.9 \%$ (95 \% CI 61.8-69.9\%). The seroprevalence among DCW (73\%) was significantly higher compared to the women not working in day care $(60 \%$; PR 1.2, $95 \%$ CI 1.1-1.4; $\mathrm{p}=0.003)$. Table 3 shows the seroprevalence per variable, as well as the results of the univariable and multivariable analyses. In a multivariable model, working at a child care centre was an independent determinant of B19V IgG-seropositivity (PR 1.2, $95 \%$ CI 1.1-1.3; $\mathrm{p}=0.002$ ). Also, in this model, being a parent of one or more children was significantly associated with B19V IgG-seropositivity (PR 1.2; 95 \% CI $1.0-1.3 ; \mathrm{p}=0.02)$. No other independent risk factors were identified.

\section{Seroprevalence of VZV antibodies IgG}

All 540 women were tested for IgG antibodies against VZV. The seroprevalence of VZV IgG antibodies in the study sample was 96.5\% (95\% CI 94.6-97.7\%). All 242 DCW were seropositive for VZV IgG antibodies (95\% CI 98.7-100.0\%), and although women from the Amsterdam general population had a high VZV IgG seroprevalence (93.6\%; $95 \%$ CI 90.2-96.2\%), this was significantly lower than among the DCW $(\mathrm{p}<0.001)$. In view of the $100 \%$ VZV seropositivity among DCW, no overall logistic regression analysis was performed. In a multivariable model restricted to the women of Amsterdam Health Monitoring Survey (no independent predictors for seropositivity were found. (Data not shown). 
Table 1 Characteristics of 242 female child day care workers in Amsterdam, The Netherlands, compared with 298 women of the Amsterdam population (2004)

\begin{tabular}{|c|c|c|c|c|c|c|c|}
\hline \multirow{2}{*}{ Characteristics } & \multirow{2}{*}{$\mathbf{N}$} & \multirow{2}{*}{$\%$} & \multicolumn{2}{|c|}{$\begin{array}{c}\text { Child Day } \\
\text { Care Workers }\end{array}$} & \multicolumn{3}{|c|}{$\begin{array}{l}\text { Population } \\
\text { sample }\end{array}$} \\
\hline & & & $\mathrm{n}$ & $\%$ & $\mathbf{n}$ & $\%$ & $p$ value \\
\hline Total & 540 & & 242 & $44.8 \%$ & 298 & $55.2 \%$ & \\
\hline \multicolumn{8}{|l|}{ Age } \\
\hline Median age in years & 32 (IQR 25-39) & 29 (IQR 24-35) & 35 (IQR 28-40) & $<0.001$ & & & \\
\hline Age (in years) & & & & & & & $<0.001$ \\
\hline$<20$ & 23 & $4.3 \%$ & 11 & $4.6 \%$ & 12 & $4.0 \%$ & \\
\hline $20-24$ & 92 & $17.0 \%$ & 51 & $21.1 \%$ & 39 & $13.1 \%$ & \\
\hline $25-29$ & 107 & $19.8 \%$ & 69 & $28.5 \%$ & 40 & $13.4 \%$ & \\
\hline $30-34$ & 90 & $16.7 \%$ & 48 & $19.8 \%$ & 42 & $14.1 \%$ & \\
\hline $35-39$ & 108 & $20.0 \%$ & 30 & $12.4 \%$ & 78 & $26.2 \%$ & \\
\hline $40-44$ & 120 & $22.2 \%$ & 33 & $13.6 \%$ & 87 & $29.2 \%$ & \\
\hline Country of birth & & & & & & & $<0.001$ \\
\hline The Netherlands & 294 & $54.4 \%$ & 176 & $72.7 \%$ & 118 & $39.6 \%$ & \\
\hline Other European countries & 25 & $4.6 \%$ & 11 & $4.6 \%$ & 14 & $4.7 \%$ & \\
\hline Suriname and Dutch Antilles & 37 & $6.9 \%$ & 26 & $10.7 \%$ & 11 & $3.7 \%$ & \\
\hline Turkey & 90 & $16.7 \%$ & 5 & $2.1 \%$ & 85 & $28.5 \%$ & \\
\hline Morocco & 66 & $12.2 \%$ & 15 & $6.2 \%$ & 51 & $17.1 \%$ & \\
\hline Other countries & 28 & $5.2 \%$ & 9 & $3.7 \%$ & 19 & $6.4 \%$ & \\
\hline Country of birth by continent & & & & & & & $<0.001$ \\
\hline The Netherlands \& Other European countries & 319 & $59.1 \%$ & 187 & $77.3 \%$ & 132 & $44.3 \%$ & \\
\hline Non-European countries* & 221 & $40.9 \%$ & 55 & $22.7 \%$ & 166 & $55.7 \%$ & \\
\hline Age at immigration & & & & & & & $<0.001$ \\
\hline $0-17$ years & 97 & $40.9 \%$ & 27 & $44.3 \%$ & 70 & $39.6 \%$ & \\
\hline 18 and older & 140 & $59.1 \%$ & 34 & $55.7 \%$ & 107 & $60.5 \%$ & \\
\hline Data missing & 9 & - & 5 & - & 4 & - & \\
\hline Not applicable (born in the Netherlands) & 294 & - & 176 & - & 118 & - & \\
\hline Having children & & & & & & & $<0.001$ \\
\hline Yes & 293 & $62.2 \%$ & 101 & $41.7 \%$ & 192 & $84.2 \%$ & \\
\hline No & 177 & $37.8 \%$ & 141 & $58.3 \%$ & 36 & $15.8 \%$ & \\
\hline Data missing & 70 & - & 0 & - & 70 & - & \\
\hline Number of children & & & & & & & $<0.001$ \\
\hline 0 & 177 & $32.8 \%$ & 141 & $58.3 \%$ & 36 & $12.1 \%$ & \\
\hline 1 & 104 & $19.3 \%$ & 46 & $19.0 \%$ & 58 & $19.5 \%$ & \\
\hline 2 & 113 & $20.9 \%$ & 35 & $14.5 \%$ & 78 & $26.2 \%$ & \\
\hline 3 & 76 & $14.1 \%$ & 20 & $8.3 \%$ & 56 & $18.8 \%$ & \\
\hline Data missing & 70 & $13.0 \%$ & 0 & $0 \%$ & 70 & $23.5 \%$ & \\
\hline
\end{tabular}

* Africa, Asia and Central and South America.

IQR; Interquartile range.

\section{Discussion}

This study demonstrates obvious differences in CMV, B19V and VZV seroprevalence between women working in Amsterdam day care centres and those who are not. In the Netherlands a population-based percentage of CMV seroprevalence is not available, yet the overall CMV seroprevalence found in this study (73 \%) corresponds to previous estimates in pregnant women in the Amsterdam area [18]. In our study, CMV seroprevalence was strongly related to ethnic background; among non-European women CMV seroprevalence was much higher (96 \%) than among European women (57\%) and this difference was constant across all age groups. It is well known that CMV seroprevalence varies worldwide, 
Table 2 Prevalence of IgG antibodies against cytomegalovirus (CMV) by demographic characteristics in female child day care workers (2007) in Amsterdam, The Netherlands, and in women of the Amsterdam population (2004) *

\begin{tabular}{|c|c|c|c|c|c|c|}
\hline \multirow{2}{*}{ Characteristics } & \multirow{2}{*}{$\frac{\text { Study Sample }}{\mathrm{N}}$} & \multicolumn{3}{|c|}{ CMV IgG Positive } & \multicolumn{2}{|c|}{ Univariable PR (95 \% Cl) } \\
\hline & & $\mathbf{n}$ & $\%$ & $p$ value & & $p$ value \\
\hline Total & 529 & 386 & $73.0 \%$ & & & \\
\hline Working in child day care & & & & 0.8 & & \\
\hline No & 288 & 209 & $72.6 \%$ & & 1 & \\
\hline Yes & 241 & 177 & $73.4 \%$ & & $1.0(0.9-1.1)$ & 0.8 \\
\hline Age (in years) & & & & 0.08 & & \\
\hline $16-24$ & 110 & 80 & $72.3 \%$ & & 1 & \\
\hline $25-34$ & 199 & 135 & $67.8 \%$ & & $0.9(0.8-1.1)$ & 0.4 \\
\hline $35-44$ & 220 & 171 & $77.7 \%$ & & $1.1(0.9-1.2)$ & 0.3 \\
\hline Country of birth & & & & $<0.001$ & & \\
\hline The Netherlands \& Other European countries & 313 & 178 & $56.9 \%$ & & 1 & \\
\hline Non-European countries** & 216 & 208 & $96.3 \%$ & & $0.6(0.5-0.7)$ & $<0.001$ \\
\hline Age at immigration & & & & $<0.001$ & & \\
\hline $0-17$ years & 95 & 88 & $92.6 \%$ & & 1 & \\
\hline 18 and older & 138 & 129 & $93.5 \%$ & & $1.0(0.9-1.1)$ & 0.8 \\
\hline Data Missing & 8 & 8 & $100 \%$ & & - & \\
\hline Not applicable (born in the Netherlands) & 288 & 161 & $55.9 \%$ & & - & \\
\hline Having children & & & & $<0.001$ & & \\
\hline No & 175 & 113 & $64.6 \%$ & & 1 & \\
\hline Yes & 288 & 236 & $81.9 \%$ & & $1.3(1.1-1.4)$ & $<0.001$ \\
\hline Data missing & 66 & 39 & $56.1 \%$ & & - & \\
\hline Number of children & & & & $<0.001$ & & \\
\hline 0 & 175 & 113 & $64.6 \%$ & & 1 & \\
\hline 1 & 103 & 76 & $73.8 \%$ & & $1.1(1.0-1.3)$ & 0.1 \\
\hline 2 & 111 & 90 & $81.8 \%$ & & $1.3(1.1-1.5)$ & 0.003 \\
\hline 3 & 74 & 70 & $94.6 \%$ & & $1.5(1.3-1.7)$ & $<0.001$ \\
\hline Number of children missing & 66 & 37 & $56.1 \%$ & & - & \\
\hline
\end{tabular}

* All analysis adjusted for day-care centre clustering.

** Africa, Asia and Central and South America.

and is related to geographic, ethnic and social factors $[19,20]$. As a consequence of the very high CMV seroprevalence among non-European women, working in day care appeared not to be related to CMV seropositivity in this group. However, within the group of women of European origin, CMV seroprevalence differed considerably between those working in child care (68\%; $95 \%$ CI 61-74\%) and those who were not (42\%; $95 \%$ CI 32-50\%), and working in child care was independently associated with CMV IgG-seropositivity (PR 1.7) among European DCW. Whilst the same association was not found for non-European DCW born (because of their high background seropositivity), they surely have a similar occupational risk of (re-)infection to that of their European colleagues.

Unlike CMV, in this study B19V seropositivity did not depend on ethnic background, although worldwide geographic differences in B19V seroprevalence (with lower B19V seroprevalence in tropical regions) are described
[20]. The B19V seroprevalence in all women of childbearing age was $66 \%$, in line with previous estimates in the overall Amsterdam population (61\%; $95 \%$ CI 57$64 \%)$ [16]. However, DCW had a significantly higher seroprevalence (73\%) compared to women not working in day care $(60 \%)$. Apart from working with children (PR 1.2), being a parent of one or more children was also associated with B19V seropositivity (PR1.2).

In this study an association between working in day care and VZV seroprevalence was not shown. Although VZV seroprevalence differed significantly between DCW (100 \%) and women not working in child care (94\%) it was not possible to control for likely confounders such as age or ethnic background. Whereas VZV seroprevalence in Dutch adults is nearly $95-100 \%$, which is typical for adults born in a temperate climate, VZV seroprevalence in immigrants from (sub)tropical countries is often lower [21]. Remarkably, in this study all DCW, including immigrant DCW, tested positive for VZV. Although it seems 
Table 3 Prevalence of IgG antibodies against parvovirus B19 by demographic characteristics in female day care workers (2007) in Amsterdam, The Netherlands, and in women of the Amsterdam population (2004)*

\begin{tabular}{|c|c|c|c|c|c|c|c|c|}
\hline \multirow{2}{*}{ Characteristics } & \multirow{2}{*}{$\frac{\text { Study Sample }}{\mathrm{N}}$} & \multicolumn{3}{|c|}{ Parvovirus B19 lgG Positive } & \multicolumn{2}{|c|}{ Univariable PR (95 \% Cl) } & \multicolumn{2}{|c|}{ Multivariable PR $(95 \% \mathrm{Cl}$} \\
\hline & & $\mathrm{n}$ & $\%$ & $p$ value & & $p$ value & & $p$ value \\
\hline Total & 540 & 356 & $65.9 \%$ & & & & & \\
\hline Working in child day care & & & & 0.003 & & & & \\
\hline No & 298 & 180 & $60.4 \%$ & & 1 & & 1 & \\
\hline Yes & 242 & 176 & $72.7 \%$ & & $1.2(1.1-1.4)$ & 0.002 & $1.2(1.1-1.4)$ & 0.002 \\
\hline Age (in years) & & & & 0.18 & & & & \\
\hline $16-24$ & 113 & 72 & $63.7 \%$ & & 1 & & 1 & \\
\hline $25-34$ & 199 & 141 & $70.9 \%$ & & $1.1(1.0-1.3)$ & 0.2 & $1.1(0.9-1.3)$ & 0.2 \\
\hline $35-44$ & 228 & 143 & $62.7 \%$ & & $1.0(0.8-1.2)$ & 0.9 & $1.0(0.8-1.3)$ & 0.7 \\
\hline Country of birth & & & & 0.75 & & & & \\
\hline The Netherlands \& Other European countries & 319 & 212 & $66.5 \%$ & & 1 & & 1 & \\
\hline Non-European countries ${ }^{* *}$ & 221 & 144 & $65.2 \%$ & & $1.0(0.9-1.1)$ & 0.73 & $1.1(0.9-1.5)$ & 0.08 \\
\hline Age at immigration & & & & 0.12 & & & & \\
\hline $0-17$ years & 97 & 71 & $73.2 \%$ & & 1 & & & \\
\hline 18 and older & 141 & 88 & $62.4 \%$ & & $0.9(0.7-1.0)$ & 0.07 & & \\
\hline Data missing & 8 & 3 & $37.5 \%$ & & - & & & \\
\hline Not applicable (born in the Netherlands) & 294 & 194 & $66.0 \%$ & & - & & & \\
\hline Having children & & & & 0.09 & & & & \\
\hline No & 177 & 114 & $64.1 \%$ & & 1 & & 1 & \\
\hline Yes & 293 & 203 & $69.3 \%$ & & $1.1(0.9-1.2)$ & 0.27 & $1.2(1.0-1.3)$ & 0.02 \\
\hline Data missing & 70 & 39 & $55.7 \%$ & & - & & - & \\
\hline Number of children & & & & 0.24 & & & - & \\
\hline 0 & 177 & 114 & $64.4 \%$ & & 1 & & & \\
\hline 1 & 104 & 73 & $70.2 \%$ & & $1.1(0.9-1.3)$ & 0.26 & & \\
\hline 2 & 113 & 80 & $70.8 \%$ & & $1.1(0.9-1.3)$ & 0.28 & & \\
\hline 3 & 76 & 50 & $65.8 \%$ & & $1.0(0.8-1.2)$ & 0.82 & & \\
\hline Number of children missing & 70 & 39 & $55.7 \%$ & & - & & & \\
\hline
\end{tabular}

* All analysis adjusted for day-care centre clustering.

** Africa, Asia and Central and South America.

plausible that some susceptible DCW may have contracted VZV after they started working in child care, data on the incidence of chickenpox in this group were not available, nor were data on the VZV serostatus at the start of the women's employment in child care. It is likely that a boosting effect from the occupational exposure to children infected by VZV has also contributed to the $100 \%$ seropositivity found among DCW [22,23]. Lastly, although the manufacturers of the two different enzyme immunoassays (VIRION and EUROIMMUN) used for the two serum samples groups quote similarly high sensitivity (>94\%), a discrepancy between the two tests may have affected the outcome.

A limitation in this study is that two demographically different populations were studied. Although the multivariable regression models adjusted for some important confounders like age, country of birth and having children, it is possible that other confounders, like socio-economic factors were missed. Also the sampling data of the populations differed (2004 and 2008), however the effect of this difference is likely to be negligible.

Despite these limitations, our results confirm that working in day care is independently associated with CMV and B19V infection. Although the occupational risk of infection in child care is not new and has been described since the 1990's [10,13,14,24-29], this knowledge has not contributed to the implementation of effective preventive policies for this particular risk group. For VZV, a safe and effective vaccine is available and although some countries have adopted guidelines to screen and vaccinate risk groups (like healthcare workers) this is not applicable to DCW [30,31]. As a consequence, pregnant DCW exposed to chickenpox still need very rapid testing, and seronegative women require post-exposure prophylaxis with human varicella-human immunoglobulin within $72 \mathrm{~h}$. For CMV and B19V, vaccines are not available, although the development of a vaccine against CMV is in progress [27,32]. Female 
DCW should be considered a risk group eligible for vaccination once the vaccine becomes available. Until that time, other preventive strategies are necessary, such as awareness campaigns to ensure pregnant women are alerted to the risks associated with exposure to CMV or B19V. This is important as several studies have described a lack of knowledge, not only among risk groups, but also among physicians about the effects of these infections during pregnancy [33-35]. Screening should be considered, especially in those who are pregnant or are trying to become pregnant, as knowledge of one's serostatus might enhance the effect of behavioural interventions and adherence to hygiene measures such as hand washing after diaper changing. In addition, the employer, the occupational physician, and the pregnant employee who is susceptible to CMV or B19V infection could agree on alternative work during at least part of the pregnancy.

\section{Conclusion}

This study shows clearly the association between employment in child day care centres and CMV and B19V infection. Also a considerable number of female DCW of childbearing age remain susceptible to B19V infection. To reduce the risk of congenital infection, widespread implementation of intervention policies, like screening of new employees (and if applicable, VZV vaccination), behavioural interventions and awareness campaigns among DCW, are strongly recommended to improve the maternal health of these women and the health of their offspring.

\section{Competing interests}

The authors declare that they have no competing financial or other interests.

\section{Acknowledgements}

The authors would like to thank Roel Coutinho for his critical review, and Sally Hebeling and Jane Whelan for editing the final manuscript.

\section{Author details}

${ }^{1}$ Public Health Service Amsterdam, Department of Infectious Diseases, Nieuwe Achtergracht 100, Amsterdam, WT 1018, The Netherlands. ${ }^{2}$ Public Health Laboratory, Cluster of Infectious Diseases, Public Health Service of Amsterdam, Nieuwe Achtergracht 100, Amsterdam, WT 1018, The Netherlands. ${ }^{3}$ Department of Internal Medicine, Division of Infectious Diseases, Tropical Medicine and AIDS, Academic Medical Centre, Meibergdreef 9, Amsterdam 1105 AZ, The Netherlands. ${ }^{4}$ Public Health Service Amsterdam, Cluster Infectious Diseases, Department of Research, Nieuwe Achtergracht 100, Amsterdam, WT 1018, The Netherlands. ${ }^{5}$ Public Health Service Amsterdam, Nieuwe Achtergracht 100, Amsterdam, WT 1018, the Netherlands.

\section{Authors' contributions}

LB and GGCVR performed the data collection. GGCvR performed the data analysis and wrote the first draft of the manuscript. MD advised and supervised the carrying out of the immunoassays. MSvdL contributed to the statistical analysis. GBS and AvdH made substantial changes to the manuscript. All authors read and approved the final manuscript.

Received: 15 December 2011 Accepted: 22 June 2012 Published: 22 June 2012

\section{References}

1. Kenneson A, Cannon MJ: Review and meta-analysis of the epidemiology of congenital cytomegalovirus (CMV) infection. Rev Med Virol 2007, 17:253-276.

2. Cohen BJ, Kumar S: Parvovirus B19 infection in pregnancy. Fetal Matern Med Rev 2005, 16:123-150

3. Arvin AM: Varicella-zoster virus. Clin Microbiol Rev 1996, 9:361-381.

4. Heininger U: Seward JF: Varicella. Lancet 2006, 368:1365-1376.

5. Dollard SC, Grosse SD, Ross DS: New estimates of the prevalence of neurological and sensory sequelae and mortality associated with congenital cytomegalovirus infection. Rev Med Virol 2007, 17:355-363.

6. Fowler KB, Stagno S, Pass RF: Maternal immunity and prevention of congenital cytomegalovirus infection. JAMA 2003, 289:1008-1011.

7. Wang C, Zhang X, Bialek S, Cannon MJ: Attribution of congenital cytomegalovirus infection to primary versus non-primary maternal infection. Clin Infect Dis 2011, 52:e11-e13.

8. Enders G, Miller E, Cradock-Watson J, Bolley I, Ridehalgh M: Consequences of varicella and herpes zoster in pregnancy: prospective study of 1739 cases. Lancet 1994, 343:1548-1551.

9. Heegaard ED, Brown KE: Human parvovirus B19. Clin Microbiol Rev 2002, 15:485-505.

10. Joseph SA, Beliveau C, Muecke CJ, Rahme E, Soto JC, Flowerdew G, Johnston L, Langille D, Gyorkos TW: Cytomegalovirus as an occupational risk in daycare educators. Paediatr Child Health 2006, 11:401-407.

11. Staras SA, Dollard SC, Radford KW, Flanders WD, Pass RF, Cannon MJ: Seroprevalence of cytomegalovirus infection in the United States, 1988-1994. Clin Infect Dis 2006, 43:1143-1151.

12. Adler SP, Manganello AM, Koch WC, Hempfling SH, Best AM: Risk of human parvovirus B19 infections among school and hospital employees during endemic periods. J Infect Dis 1993, 168:361-368.

13. Cartter ML, Farley TA, Rosengren S, Quinn DL, Gillespie SM, Gary GW, Hadler $J$ : Occupational risk factors for infection with parvovirus B19 among pregnant women. J Infect Dis 1991, 163:282-285

14. Stelma FF, Smismans A, Goossens VJ, Bruggeman CA, Hoebe CJ: Occupational risk of human Cytomegalovirus and Parvovirus B19 infection in female day care personnel in the Netherlands; a study based on seroprevalence. Eur J Clin Microbiol Infect Dis 2009, 28:393-397.

15. Agyemang C, Ujcic-Voortman J, Uitenbroek D, Foets M, Droomers M: Prevalence and management of hypertension among Turkish, Moroccan and native Dutch ethnic groups in Amsterdam, the Netherlands: The Amsterdam Health Monitor Survey. J Hypertens 2006, 24:2169-2176.

16. van Rijckevorsel GG, Sonder GJ, Schim van der Loeff MF, van den Hoek JA: Population-based study on the seroprevalence of parvovirus B19 in Amsterdam. J Med Virol 2009, 81:1305-1309.

17. Fassaert T, de Wit MA, Verhoeff AP, Tuinebreijer WC, Gorissen WH, Beekman AT, Dekker J: Uptake of health services for common mental disorders by first-generation Turkish and Moroccan migrants in the Netherlands. BMC Publ Health 2009, 9:307.

18. Gaytant MA, Galama JM, Semmekrot BA, Melchers WJ, Sporken JM, Oosterbaan HP, van Dop PA, Huisman A, Merkus HM, Steegers EA: The incidence of congenital cytomegalovirus infections in The Netherlands. J Med Virol 2005, 76:71-75.

19. Staras SA, Flanders WD, Dollard SC, Pass RF, McGowan JE Jr, Cannon MJ: Cytomegalovirus seroprevalence and childhood sources of infection: A population-based study among pre-adolescents in the United States. J Clin Virol 2008, 43:266-271.

20. Cannon MJ, Schmid DS, Hyde TB: Review of cytomegalovirus seroprevalence and demographic characteristics associated with infection. Rev Med Virol 2010, 20:202-213.

21. de Melker H, Berbers $G$, Hahne S, Rumke H, van den Hof S, de Wit A, Boot H: The epidemiology of varicella and herpes zoster in The Netherlands: implications for varicella zoster virus vaccination. Vaccine 2006, 24:3946-3952.

22. Brisson M, Gay NJ, Edmunds WJ, Andrews NJ: Exposure to varicella boosts immunity to herpes-zoster: implications for mass vaccination against chickenpox. Vaccine 2002, 20:2500-2507.

23. Thomas SL, Wheeler JG, Hall AJ: Contacts with varicella or with children and protection against herpes zoster in adults: a case-control study. Lancet 2002, 360:678-682. 
24. Gilbert NL, Gyorkos TW, Beliveau C, Rahme E, Muecke C, Soto JC: Seroprevalence of parvovirus B19 infection in daycare educators. Epidemiol Infect 2005, 133:299-304.

25. Gillespie SM, Cartter ML, Asch S, Rokos JB, Gary GW, Tsou CJ, Hall DB, Anderson $L$, Hurwitz ES: Occupational risk of human parvovirus B19 infection for school and day-care personnel during an outbreak of erythema infectiosum. JAMA 1990, 263:2061-2065.

26. Murph JR, Baron JC, Brown CK, Ebelhack CL, Bale JF Jr: The occupational risk of cytomegalovirus infection among day-care providers. JAMA 1991, 265:603-608.

27. Pass RF, Hutto C, Lyon MD, Cloud G: Increased rate of cytomegalovirus infection among day care center workers. Pediatr Infect Dis J 1990, 9:465-470.

28. Ludwig A, Hengel H: Epidemiological impact and disease burden of congenital cytomegalovirus infection in Europe. Euro Surveill 2009, 14:26-32. http://www.eurosurveillance.org/NiewArticle.aspx?Articleld=19140.

29. Pandolfi E, Chiaradia G, Moncada M, Rava L, Tozzi AE: Prevention of congenital rubella and congenital varicella in Europe. Euro Surveill 2009, 14:16-20. http://www.eurosurveillance.org/NiewArticle.aspx?Articleld=19133.

30. Dutch Institute for Healthcare Improvement (CBO): Varicella Guidelines; 2010. http://www.cbo.nl/thema/Richtlijnen/Overzicht-richtlijnen/Infectieziekten/.

31. The UK National Screening Committee (NSC): Antenatal Screening for Susceptibility to Varicella Zoster Virus (VZV) in the United Kingdom; 2009. http://www.screening.nhs.uk/varicella.

32. Griffiths $P$ : The beginning of the end of a long wait for a vaccine against cytomegalovirus. Rev Med Virol 2009, 19:117-119.

33. Jeon J, Victor M, Adler SP, Arwady A, Demmler G, Fowler K, Goldfarb J, Keyserling H, Massoudi M, Richards K, et al: Knowledge and awareness of congenital cytomegalovirus among women. Infect Dis Obstet Gynecol 2006, 2006:80383.

34. Korver AM, de Vries JJ, de Jong JW, Dekker FW, Vossen AC, OudesluysMurphy AM: Awareness of congenital cytomegalovirus among doctors in the Netherlands. J Clin Virol 2009, 46(Suppl 4):S11-S15.

35. Vossen A, de Vries J, van der Zeijst B: The 2008 congenital cytomegalovirus conference, 5-7 November, Centers for Disease Control and Prevention, Atlanta. Euro Surveill 2009, 14:37-38. http://www. eurosurveillance.org/NiewArticle.aspx?Articleld=19136

doi:10.1186/1471-2458-12-475

Cite this article as: Rijckevorsel et al: Increased seroprevalence of IgGclass antibodies against cytomegalovirus, parvovirus B19, and varicellazoster virus in women working in child day care. BMC Public Health 2012 $12: 475$

\section{Submit your next manuscript to BioMed Central and take full advantage of:}

- Convenient online submission

- Thorough peer review

- No space constraints or color figure charges

- Immediate publication on acceptance

- Inclusion in PubMed, CAS, Scopus and Google Scholar

- Research which is freely available for redistribution 